\title{
Modernisation Trends in Public Administration in Slovenia
}

\section{Simona Kukovič \\ Gorazd Justinek ${ }^{* *}$}

\author{
https://doi.org/10.31297/hkju.20.4.2 \\ UDK 35.071(497.4) \\ Original scientific paper / izvorni znanstveni rad \\ Received / primljeno: $\quad$ 20.06.2020. \\ Accepted / prihvaćeno: 27.11.2020.
}

Although no longer appropriate, the classical model of bureaucratic organisation (Weber) still remains the basis of public administration. First major reforms in public administration were introduced by market-oriented New Public Management, but recently, as a reflection of social and political changes, Post-New Public Management approaches have developed. The paper puts an emphasis on modern approaches, which do not appear in pure form but in the form of hybrids. The decision on the optimal direction of public administration development is left to the states, bearing in mind that each public administration reform

* Simona Kukovič, Assistant Professor, Faculty of Social Sciences, University of Ljubljana, Slovenia (docentica Fakulteta društvenih znanosti Sveučilišta u Ljubljani, Slovenija, e-mail: simona.kukovic@fdv.uni-lj.si)

ORCID ID: https://orcid.org/0000-0003-3717-9019

** Gorazd Justinek, Assistant Professor, Faculty of Government and European Studies, New University, Kranj, Slovenia (docent Fakulteta za državne i europske studije Novog sveučilišta u Kranju, Slovenija, e-mail: gorazd.justinek@gmail.com)

ORCID ID: https://orcid.org/0000-0002-7229-6280 
and hybridisation of approaches affect the complexity of public administration. The paper analyses the Slovenian public administration reform, where we find that the current public administration development strategy is based on modern elements and values of different theoretical doctrines, like Post-New Public Management approaches, but (as shown by the current Covid-19 crisis) that diverse efforts are required in the future to achieve this goal.

Keywords: public administration, reforms, new approaches, modernisation, Slovenia

\section{Introduction}

In today's globalised society, when the world has become a global village, activities on one side of the world have an impact on events and activities on the other side of the world. This was not the case just a decade ago (Justinek, 2020; Philippi et al., 2020). The financial and economic crisis of 2008/2009 clearly showed how financial and economic activities are globally interconnected nowadays. The key driver of this global interconnection is undoubtedly constant change. That the change is the only constant is true not only for individuals but also for the hegemon of public administration. If only a few decades ago it was considered that the private sector adapts and the public sector remains, with globalisation this has also changed (Letnar Černič \& Justinek, 2020). Administrative reforms remain a part of everyday life of modern countries, which are, under the weight of external and internal triggers, (more or less successfully) looking for new ways of managing the public sector. The latter is particularly true for the new democracies of Central and Eastern Europe, which experienced the first wave of administrative reforms with the (re-)establishment of public administration in an independent state, with the aim of cutting through the patterns of action of the previous system; the second wave was experienced in the processes of rapprochement and entering into the European Union.

The enlargement of the European Union to the transition countries of Central and Eastern Europe - despite the fact that previous enlargements did not assess the administrative systems of the candidate countries - has led to a thorough analysis of the readiness of their administrations to join the club. That is so due to the fact that the administrative reform in these 
countries lagged behind political and economic reforms (Brezovšek \& Kukovič, 2015). When the Council of the European Union opened the prospect of enlargement to the countries of Central and Eastern Europe in Copenhagen in 1993, it set out the criteria ${ }^{1}$ that the candidate countries had to meet in order to become full members. In addition, the Madrid Criterion, adopted in 1995, addressed the administrative (institutional) capacity and is one of the most important criteria for the membership, as potential members have been forced to modernise their administration, especially by creating professional staff and strengthening institutional capacity to implement European Union law (Olsen, 2003, pp. 519-522). ${ }^{2}$

The core of the analysis in the paper is focused on the reforms of public administration in Slovenia, which has undergone quite radical changes in the process of approaching and joining the European integration. The latter does not mean that public administration reforms ended with the confirmation of full EU membership. Rather the reforms (although less radical and with an emphasis on the inclusion of modern elements) continued, especially due to triggers from the dynamic (international) environment. The goal of the paper is to present the dynamic of the Slovenian public administration reform(s) and to highlight how elements of modern approaches have been introduced through strategic documents into the functioning of the public administration system. In the analysis, we put an emphasis on the Public Administration Development Strategy 2015-2020 (2015), which advocates expertise, professionalism, stability, implementation of administrative tasks for users and satisfaction of participants, to name just a few. From the point of view of administrative theories, in this strategy we perceive a departure from the classical approach to management towards modern Post-New Public Management approaches, and the inclusion of values and elements essential to these new approaches. For this purpose, we set the following hypothesis: "In accordance with modern theoretical doctrines, the Public Administration Development Strategy 2015-2020 goes beyond the concept of New Public Management."

1 The Copenhagen Criteria are divided into three pillars, namely the political criteria, economic criteria, and legal criteria (SIGMA/OECD, 1998, p. 80).

2 The 1997 Luxembourg Criterion identified strengthening, improvement, and more robust institutional arrangements; two years later, the Helsinki Criterion stipulated that the candidate countries must respect the common values and objectives of the Union, as set out in the treaties. 
The paper is based on a content analysis of primary and secondary sources, and at various points includes elements of self-assessment. Following the introduction, the content is divided into four parts, namely: the theoretical starting points, where we prepared an overview of the transition from classical to modern administrative approaches; a review of the Slovenian public administration reforms; an analysis of the currently valid strategy; and an assessment of the state of administrative reforms as well as aspirations for the modernisation of public administration in the Republic of Slovenia.

\section{Transitions of Administrative Approaches: from the Classical Weber Model towards Modern Approaches to Management}

The beginning of the traditional model of public administration - despite the fact that rudiments of administrative models existed before - is considered to date back to the beginning of the 20th century, when Weber developed the concept of the modern state simultaneously with the development of bureaucratic-administrative structures (Hughes, 2003, p. 18). As the three main pillars that the formal structure of bureaucracy must contain, Weber stated: division of labour, hierarchical arrangement, and impersonality of rules (more in Brezovšek, Haček \& Kukovič, 2014, pp. 40-41). Although the bureaucratic model has been relatively ineffective in practice, it has remained dominant for a long time, despite numerous criticisms and amendments.

The need for public administration reform was already indicated by Saint-Simon (1979, p. 206), who wrote that the rule over people should be replaced by the management of things; even more influential was Wilson (1995, p. 25), who explained that the process of running a country is becoming increasingly complex due to population growth as well as other social and economic aspects, and therefore needs comprehensive change. In doing so, Wilson still proceeded from the primary purpose of public administration, which is to provide for and meet the needs of the state and citizens, but in this concept he went beyond Weber's definition of public administration as bureaucratic organisation and began to think about public administration in correlation with the economy of the private sector. Namely, he believed that for optimal efficiency and effective- 
ness of public administration, approaches from the private sector should be transferred to the management and operation of public administration. Despite the initial enthusiasm for the neoliberal approach to public administration management, i.e. New Public Management, which, in contrast to the classic bureaucratic organisation, emphasises transparency, decentralisation, the introduction of managerial-entrepreneurial management and other elements of the private sector, due to sharp criticisms of inefficiency and even corruption the enthusiasm faded quickly. Based on criticisms of previous approaches, new ideas and various attempts to manage public administration, a reform movement known as the so-called Post-New Public Management developed, which is inter-organisational and strives to improve the horizontal coordination of the government organisation and assure greater coordination between the government and other actors (Lodge \& Gill, 2011). Post-New Public Management is focused on the user - citizen, uses a holistic management style, enforces the skills of transcending separation and common goals, focuses on procedures, impartiality, ethical norms, and stronger central control. If the return to the centre is more focused on the restoration of the hierarchy, however, the increased effort to coordinate, cohere and transcend the boundaries of different jurisdictions is linked to governance in terms of network and partnerships. Post-New Public Management therefore advocates a more holistic strategy, for which the terms "joined-up government" and "whole-of-government" are used, and is focused on integration (Brezovšek, Haček \& Kukovič, 2014, pp. 68-69).

On this basis, new organisational forms have been established within Post-New Public Management, replacing hierarchy and the market as mechanisms for the coordination of public administration, i.e. mainly elements of governance, partnership, and network. In the scientific field, there is (yet) no consensus on the effects of new elements and structures, nor is there a common naming of the beginning of the new model, but there is a consensus among the scientific community on the need to further develop both theory and practice (see Fisher, 2014). In these new approaches, other values are more important than the values of efficiency and effectiveness, in particular the emphasis on democracy. New emerging views on the development and reform of public administration are recorded in the form of various initiatives such as New Public Governance (Osborne, 2006; 2010), Neo-Weberian State (Pollitt \& Bouckaert, 2004; Dunn \& Miller, 2007), Digital-Era Governance (Dunleavy et al., 2005), Public Value Management (Stoker, 2006), and others. The concept of New Public Service also emerges, embracing much of this participatory 
and democratic spirit, content, and focus on governance (Denhardt \& Denhardt, 2003).

Table 1. Comparison of paradigms: New Public Governance, Neo-Weberian State, Digital-Era Governance and Public Value Management

\begin{tabular}{|c|c|c|c|c|}
\hline & $\begin{array}{l}\text { New Public } \\
\text { Governance }\end{array}$ & $\begin{array}{l}\text { Neo-Weberian } \\
\text { State }\end{array}$ & $\begin{array}{l}\text { Digital-Era } \\
\text { Governance }\end{array}$ & $\begin{array}{l}\text { Public Value } \\
\text { Management }\end{array}$ \\
\hline $\begin{array}{l}\text { Funda- } \\
\text { mental } \\
\text { idea }\end{array}$ & $\begin{array}{l}\text { Relations between } \\
\text { parts of the society } \\
\text { require coopera- } \\
\text { tion, networking } \\
\text { solutions, partner- } \\
\text { ship and coopera- } \\
\text { tion with citizens }\end{array}$ & $\begin{array}{l}\text { Renovated } \\
\text { and reinforced } \\
\text { bureaucracy, } \\
\text { based on } \\
\text { European state } \\
\text { tradition }\end{array}$ & $\begin{array}{l}\text { Digital age } \\
\text { requires } \\
\text { integration, } \\
\text { holism and } \\
\text { digitalisation } \\
\text { as a lever of } \\
\text { reform }\end{array}$ & $\begin{array}{l}\text { Public managers } \\
\text { with strategy } \\
\text { and innovation } \\
\text { co-create public } \\
\text { values for citi- } \\
\text { zens as well as } \\
\text { short- and long- } \\
\text { term policies }\end{array}$ \\
\hline $\begin{array}{l}\text { Rejection } \\
\text { of New } \\
\text { Public } \\
\text { Manage- } \\
\text { ment due } \\
\text { to ... }\end{array}$ & $\begin{array}{l}\text { Too much atten- } \\
\text { tion on the market } \\
\text { and output results } \\
\text { means that there is } \\
\text { not enough space } \\
\text { for cooperation be- } \\
\text { tween and across } \\
\text { organisational } \\
\text { boundaries }\end{array}$ & $\begin{array}{l}\text { New Public } \\
\text { Management } \\
\text { has lost its } \\
\text { sense of values } \\
\text { associated with } \\
\text { the major part } \\
\text { of bureaucracy } \\
\text { and the rule } \\
\text { of law }\end{array}$ & $\begin{array}{l}\text { Market } \\
\text { solutions are } \\
\text { not enough } \\
\text { to search for } \\
\text { new opportu- } \\
\text { nities offered } \\
\text { by digitalisa- } \\
\text { tion and the } \\
\text { web }\end{array}$ & $\begin{array}{l}\text { (New Public) } \\
\text { Managers are } \\
\text { too focused } \\
\text { on short-term } \\
\text { results }\end{array}$ \\
\hline $\begin{array}{l}\text { Key sup- } \\
\text { porters }\end{array}$ & $\begin{array}{l}\text { Osborne, Kette, } \\
\text { Lynn }\end{array}$ & $\begin{array}{l}\text { Pollitt, Bouck- } \\
\text { aert }\end{array}$ & $\begin{array}{l}\text { Dunleavy, } \\
\text { Fountain }\end{array}$ & $\begin{array}{l}\text { Moore, Alford, } \\
\text { O'Flynn }\end{array}$ \\
\hline $\begin{array}{l}\text { Weak- } \\
\text { nesses }\end{array}$ & $\begin{array}{l}\text { Is cooperation } \\
\text { as pervasive as } \\
\text { claimed by the } \\
\text { supporters? }\end{array}$ & $\begin{array}{l}\text { It is not cer- } \\
\text { tain that the } \\
\text { bureaucracy } \\
\text { can change the } \\
\text { way of work- } \\
\text { ing, as seen by } \\
\text { supporters }\end{array}$ & $\begin{array}{l}\text { Excessive } \\
\text { enthusiasm } \\
\text { for digital } \\
\text { technology }\end{array}$ & $\begin{array}{l}\text { Is the regulato- } \\
\text { ry framework } \\
\text { too rigid for } \\
\text { the managers' } \\
\text { strategy? Is this } \\
\text { even good for } \\
\text { managers? }\end{array}$ \\
\hline
\end{tabular}

Source: Slovenian version of the table published in Brezovšek \& Kukovič (2015, p. 70).

New Public Governance is one of the alternatives to both traditional public administration and New Public Management. If governance refers to a change in the role, structure, and operational processes of the government or to the way social problems are solved, New Public Governance is an institution of social coordination based on the logic of co-management (steering and management) and the network. New Public Governance is a holistic paradigm because it is a more comprehensive and integrated approach to public service delivery than New Public Management, and 
emphasises processes, outcomes and stable inter-organisational relationships, where trust is a key governance mechanism.

In addition to New Public Governance, New Public Service also emphasises the importance of democracy and argues that the public sector must be focused on citizens, on the community, and on civil society. The origins of this approach can be found in the theory of democratic citizenship, community and civil society models, organisational humanism, and post-modern public administration (Denhardt \& Denhardt, 2003, p. 27). At its core, New Public Service advocates seven principles, which are: serving citizens and not consumers; seeking and pursuing the public interest; evaluation of citizenship over entrepreneurship; strategic thinking, democratic action; recognising and emphasising that responsibility is not easy; service to citizens, not authoritarian leadership; and valuing people, not just productivity (Denhardt \& Denhardt, 2000, p. 549; more in Brezovšek, Haček \& Kukovič, 2014, pp. 82-87). These are the principles that, on the one hand, define the New Public Service and at the same time separate it from previous paradigms. Table 2 offers a comparison between traditional public administration, New Public Management and New Public Service.

Table 2. Comparison of approaches: Bureaucratic organisation, New Public Management and New Public Service

\begin{tabular}{|l|l|l|l|}
\hline & \multicolumn{1}{|c|}{$\begin{array}{c}\text { Classical public } \\
\text { administration }\end{array}$} & \multicolumn{1}{|c|}{$\begin{array}{c}\text { New Public } \\
\text { Management }\end{array}$} & \multicolumn{1}{|c|}{ New Public Service } \\
\hline $\begin{array}{l}\text { Primary } \\
\text { theoretical and } \\
\text { epistemologi- } \\
\text { cal foundations }\end{array}$ & $\begin{array}{l}\text { Political theory, } \\
\text { social and political } \\
\text { explanation, naive } \\
\text { social science }\end{array}$ & $\begin{array}{l}\text { Economic theory, } \\
\text { positivist social } \\
\text { science }\end{array}$ & $\begin{array}{l}\text { Democratic theory, } \\
\text { varied approaches to } \\
\text { knowledge (critical, } \\
\text { postmodern) }\end{array}$ \\
\hline $\begin{array}{l}\text { Prevailing } \\
\text { rationality and } \\
\text { models of hu- } \\
\text { man behaviour }\end{array}$ & $\begin{array}{l}\text { Synoptic rational- } \\
\text { ity, administrative } \\
\text { model, public } \\
\text { interest }\end{array}$ & $\begin{array}{l}\text { Technical and } \\
\text { economic ration- } \\
\text { ality, } \\
\text { economic model, } \\
\text { self- interest }\end{array}$ & $\begin{array}{l}\text { Strategic rationality, } \\
\text { multiple tests of rationali- } \\
\text { ty (political, economic, } \\
\text { organisational), interest } \\
\text { of citizens }\end{array}$ \\
\hline $\begin{array}{l}\text { Conception } \\
\text { of the public } \\
\text { interest }\end{array}$ & $\begin{array}{l}\text { Politically defined } \\
\text { and expressed in } \\
\text { law }\end{array}$ & $\begin{array}{l}\text { Aggregation } \\
\text { of individual } \\
\text { interests }\end{array}$ & $\begin{array}{l}\text { Result of a dialogue } \\
\text { about shared values }\end{array}$ \\
\hline $\begin{array}{l}\text { Dependence of } \\
\text { civil servants }\end{array}$ & $\begin{array}{l}\text { Clients/constitu- } \\
\text { ents }\end{array}$ & Customers & Citizens \\
\hline
\end{tabular}




\begin{tabular}{|l|l|l|l|}
\hline $\begin{array}{l}\text { Role of govern- } \\
\text { ment }\end{array}$ & $\begin{array}{l}\text { Rowing } \\
\text { (focusing on } \\
\text { politically defined } \\
\text { objective) }\end{array}$ & $\begin{array}{l}\text { Steering } \\
\text { (management) }\end{array}$ & $\begin{array}{l}\text { Serving } \\
\text { (negotiating and bro- } \\
\text { kering interests among } \\
\text { citizens; shared values) }\end{array}$ \\
\hline $\begin{array}{l}\text { Mechanisms } \\
\text { for achieving } \\
\text { policy objec- } \\
\text { tives }\end{array}$ & $\begin{array}{l}\text { Administering } \\
\text { programmes, gov- } \\
\text { ernment agencies }\end{array}$ & $\begin{array}{l}\text { Private and } \\
\text { non-profit agen- } \\
\text { cies }\end{array}$ & $\begin{array}{l}\text { Coalitions of public, } \\
\text { non-profit, and private } \\
\text { agencies to meet mutual- } \\
\text { ly agreed upon needs }\end{array}$ \\
\hline Accountability & $\begin{array}{l}\text { Hierarchical } \\
\text { (civil servants are } \\
\text { responsible to the } \\
\text { government and } \\
\text { democratically } \\
\text { elected political } \\
\text { leaders) }\end{array}$ & $\begin{array}{l}\text { Market-driven } \\
\text { (focus on achiev- } \\
\text { ing results) }\end{array}$ & $\begin{array}{l}\text { Multifaceted } \\
\text { (public servants must } \\
\text { attend to law, values, } \\
\text { political norms, citizen } \\
\text { interests and professional } \\
\text { standards) }\end{array}$ \\
\hline $\begin{array}{l}\text { Administrative } \\
\text { discretion }\end{array}$ & $\begin{array}{l}\text { Limited; allowed } \\
\text { administrative } \\
\text { officials }\end{array}$ & $\begin{array}{l}\text { Wide to meet } \\
\text { entrepreneurial } \\
\text { goals }\end{array}$ & $\begin{array}{l}\text { Needed but constrained } \\
\text { and accountable }\end{array}$ \\
\hline $\begin{array}{l}\text { Organisational } \\
\text { structure }\end{array}$ & $\begin{array}{l}\text { Bureaucratic, top- } \\
\text { down authority, } \\
\text { control or regula- } \\
\text { tion of clients }\end{array}$ & $\begin{array}{l}\text { Decentralised } \\
\text { with primary con- } \\
\text { trol remaining } \\
\text { within the agency }\end{array}$ & $\begin{array}{l}\text { Collaborative with } \\
\text { (internally and externally) } \\
\text { shared leadership }\end{array}$ \\
\hline $\begin{array}{l}\text { Motivation of } \\
\text { public servants }\end{array}$ & $\begin{array}{l}\text { Pay, benefits, } \\
\text { civil-service protec- } \\
\text { tions }\end{array}$ & $\begin{array}{l}\text { Entrepreneurial } \\
\text { spirit, desire to } \\
\text { reduce the size of } \\
\text { government }\end{array}$ & $\begin{array}{l}\text { Public service, desire to } \\
\text { contribute to the society } \\
\text { (common/public good) }\end{array}$ \\
\hline
\end{tabular}

Sources: summarised after Denhardt \& Denhardt (2000, p. 554); Brezovšek, Haček \& Kukovič, $(2014$, p. 80).

As we can notice, the New Public Service is not something completely new, but a return to the understanding and awareness of the public service in terms of its foundations and origins, i.e. the public and the service (Denhardt \& Denhardt, 2003, pp. 3-4). This approach is therefore about focusing on public action, commitment to the public service, and assertion of the public interest.

We can observe that the mentioned Post-New Public Management paradigms wanted to preserve the basic idea of New Public Management, but at the same time contain lessons learned from criticism towards New Public Management. These paradigms include firstly New Public Governance, which is essentially New Public Management with the learned elements of the Weberian doctrine, focusing more on public policies than implementation, as well as Public Value Management, joined-up, whole-of-government with a focus on coordination, and more. In addition, we must not forget the remaining protagonists of the two main older paradigms and even their new followers or converts. 
In reviewing the transition of different (modern) approaches in public administration, we would like to highlight the concept of the Neo-Weberian State, also known as the European concept of public administration reform, which has proven to be a reliable and feasible alternative to New Public Management. The concept of the Neo-Weberian State was introduced by Pollitt and Bouckaert (2004; 2011), who presented it as a model of public administration reform, perhaps even as a political orientation (Drechsler \& Kattel, 2008), as it embraces the ideas of political power and modernisation. The concept of the Neo-Weberian State is a system of bureaucratic organisation with lessons learned from the practice of New Public Management, but it goes beyond just a mixture of these two approaches, as it also contains "neo" and modernising elements. According to Brezovšek and Kukovič (2015, p. 72), elements of bureaucratic organisation represent the backbone of public administration and are supplemented (and not replaced) by managerial (neo) elements. The concept of the Neo-Weberian State is therefore a feasible Post-Post-New Public Management that not only corrects the key shortcomings of New Public Management, but transcends the "bureaucratic model versus managerial model" dichotomy and replaces it with a more comprehensive interpretation addressing three poles instead of two. In doing so, the concept of the Neo-Weberian State is a tertium quid (Ongaro, 2013), which explains what happened to Weber's bureaucratic organisation after waves of reforms of New Public Management, as well as after Post-New Public Management.

Table 3 Neo-Weberian State in terms of going beyond the New Public Management

\begin{tabular}{|c|c|}
\hline Neo-Weberian State & $\begin{array}{l}\text { Exceedances of New Public Manage- } \\
\text { ment in the Neo-Weberian State model }\end{array}$ \\
\hline $\begin{array}{l}\text { - External orientation to the needs of citi- } \\
\text { zens; } \\
\text { - The central role of professional managers; } \\
\text { - Unitary state and cooperation; } \\
\text { - Ethos of public service; } \\
\text { - Supplement to democracy with consulta- } \\
\text { tion and participation; } \\
\text { - Separation of politics and administration } \\
\text { and an emphasis on professionalism of ad- } \\
\text { ministration }\end{array}$ & $\begin{array}{l}\text { - Networking; } \\
\text { - Less hierarchical, more cooperative } \\
\text { model of public administration; } \\
\text { - Cooperation and knowledge exchange } \\
\text { between the different levels; } \\
\text { - Quality management (objectives); } \\
\text { - Professionally efficient administration; } \\
\text { - E-administration }\end{array}$ \\
\hline
\end{tabular}

Source: Slovenian version of the table published in Brezovšek \& Kukovič (2015, p. 72). 
In a globalised and competitive environment of the $21^{\text {st }}$ century, modernisation and development of a democratic and efficient public administration are the goals of normative regulations and activities for good/sound public governance. ${ }^{3}$ Continuous improvement of the quality of services and equal access to them has therefore become a standard that implies the need for public administration reforms and regulations in a changing social environment. In the next chapter, we analyse the reform of the Slovenian public administration, paying particular attention to the perception of elements characteristic of modern Post-New Public Management approaches.

\section{The Six Waves of the Slovenian Public Administration Reforms}

As such, public administration is the whole of all management activities that fall under the executive, administrative, and managerial functions of public governance, regardless of whether they are performed by state administrative bodies, other state bodies or organisations outside the state administration, and regardless of whether they are performed in an authoritative position. Public administration consists of a circle of bodies connected to a particular system, authorised by each community to decide on matters within the competence of that community. Public administration is therefore administration in public affairs (Bučar, 1969, p. 39). The public administration system consists of four areas (Šmidovnik, 1985): state administration, which is the central territorial administrative system and an instrument of the state for the performance of its primarily authoritative functions, with which it regulates relations in the society in a legal manner; local self-government, which is a way of managing social affairs that is directly based on the local community and represents the local territorial administrative system; public services, which are those activities that provide public goods and public services that are absolutely necessary for the functioning of the social system but which, for various reasons, cannot be adequately provided by the market exchange system; and the public sector, which is based on the criterion of state ownership, hence everything that is state-owned belongs here, regardless of the field in which it operates. In practice, the Slovenian public administration

3 It is a concept that includes a legally oriented set of rights to good governance, with greater emphasis on the governance process, consideration of institutions and actors outside the administration, the principles of openness, coherence, efficiency, accountability, and citizen participation in public policy making. 
therefore consists of the state administration with ministries, government offices, agencies within ministries, and 58 administrative units (a total of just over 30,000 employees); local self-government with 212 municipalities, employing about 5,300 people; a few hundred legally autonomous entities in the form of public institutes, agencies and funds, ${ }^{4}$ which, bearing in mind that these entities are part of the public administration or the public sector in the performance of public tasks at least partially financed from the state budget, employ around 120,000 people; and entities to which municipalities or the state have delegated certain authorisations (these are private holders of public authorisations or concession providers of public services) (Ministry of Public Administration, 2020).

The chronological overview of the Slovenian public administration reforms starts from the period of independence, as the first public administration reforms were mainly related to the needs of the newly formed state. First of all, it was necessary to make the transition from the previous socialist system, to develop one's own public administration and to establish local self-government, and at the same time to provide quality services and upgrade (social) rights. Therefore, the aim of the first wave was to introduce new ways of working that would contribute to the rationalisation, efficiency, and effectiveness of public administration. The reform brought a more systematic approach, which resulted in the elements of the classical bureaucratic organisation being pushed into the background, and the elements of New Public Management being brought to the fore. The basic goal of this reform was the introduction of a new public administration function and the development of modern institutional forms capable of implementing changes in Slovenia's social and economic system and its support for EU integration and, last but not least, capable of increasing public administration efficiency. The indicative target areas of this reform were delegation of competencies and increase of work flexibility; control mechanisms and enforcement of responsibilities; competitiveness and choice in performing administrative functions; user-oriented public services; human resources management; modern information technology; and improvement of legal regulations (Presentation of the strategic plan for the implementation of the public administration reform project in Slovenia in the period 1997-1999, 1997). Brezovšek (2000, p. 277) explains that the previous reform of public administration took place simultaneously with extensive economic and political reforms, and that the process-

\footnotetext{
${ }^{4}$ Such as hospitals, schools, social welfare institutions, and others.
} 
es of democratisation, pluralisation, liberalisation, and deregulation had a strong and significant impact on the direction of the reform.

Despite ambitious target areas and announced changes that reflected elements of New Public Management and even Post-New Public Management, some authors ${ }^{5}$ believe that only a few have been implemented due to fluctuating political support and time constraints. The rest were partly transferred to a later period (basically during the second wave), when the Slovenian public administration underwent a more comprehensive reform, dictated by the process of accession, coordination, and, finally, integration into the European Union. The main objectives of this public administration reform between 2000 and 2003 were not defined in a specific strategy paper, but in the context of legislation. At this point, it is necessary to point out the year 2002, when in the light of Slovenia's accession to the European Union (or just because of it), a package of reforms was adopted, including various laws, ${ }^{6}$ aimed at the professionalisation, depoliticisation, decentralisation, and rationalisation of public administration. Slovenian public administration was thus forced to adapt its administrative culture and develop professional strategic planning of public policies, while involving citizens in consultation and decision-making processes. The Strategy on Further Development of the Slovenian Public Sector 2003-2005 (2003) was adopted, the aim of which was to create a public administration that would operate according to the principles of legality, legal certainty and predictability, political neutrality, user orientation, openness and transparency, quality, and effectiveness and efficiency. ${ }^{7}$ The main priority areas of the strategy were human resources management, functional and organisational restructuring

${ }^{5}$ See Brezovšek (2000), Kovač (2004), and others.

6 i.e. the State Administration Act, Civil Servants Act, Public Agencies Act, and others.

7 OECD (SIGMA/OECD, 1999, pp. 8-14), in the context of the European Union call for horizontal administrative reform in the countries of Central and Eastern Europe, divided the principles of administrative law into four groups (reliability and predictability, openness and transparency, responsibility, efficiency and effectiveness), while the White Paper on European Governance (2001) added additional four principles (proportionality, subsidiarity, cooperation and coordination) to the mix. The mentioned principles not only have theoretical value, but by uniform application of these principles in the administrative law of national administrations, they represent parameters for setting administrative standards and imply convergence, Europeanisation, and administrative dynamics, as they create conditions for efficiency and capacity-building of public administration and its de-politicisation. The latter is important for the equality of implementation, development, and ultimately the effects of public policies, and includes certain standards that relate primarily to the civil service system, its administrative regulation, and the policy of administrative staff (Brezovšek \& Kukovič, 2015; see also Haček, 2006; Haček, 2012). In the case of most recent EU enlargements (Croatia, Romania, and Bulgaria), the latter has become apparent, as many of them have not yet fully 
of public administration, business processes in administration and e-government in terms of standardisation, optimisation and informatisation of administrative procedures and other business processes, quality management in administration and public orientation, administration to the user, open public administration, increasing the economy and efficiency of the use of public funds, and the performance of the state sector.

We can say that after the successful integration of Slovenia into the European Union in 2004, Slovenian public administration was hit by the third wave of reforms. At that time, public administration went through a period of modernisation of the political-administrative system ${ }^{8}$ and "Europeanisation" of the administrative system, also in terms of placement in the concept of the European administrative space. ${ }^{9}$ Above all, it was crucial to establish thinking or internalise the awareness that Slovenia, and with it above all its administration, is part of the EU internal market, that it is part of the EU. In practice, this often meant that it was necessary to transfer the activities, which until then had in principle been concentrated in the departments or sectors for international and European affairs of individual public bodies, to all levels of their operation.

Then, relatively quickly after this period of general growth, the financial and economic crisis hit, where the EU failed to find a coordinated and, above all, rapid response. The latter also in Slovenia required adjustments by the public administration to deal with and manage the consequences of the economic and financial contraction. Due to the mentioned global economic crisis, Slovenian public administration was forced to adjust to a new reality and to respond, which caused the fourth wave of reforms. Therefore, in 2010 the Slovenian Government adopted a document entitled Slovenian Exit Strategy 2010-2013 (2010), with which it wanted to stimulate economic activity as soon as possible and ensure a gradual elimination of macroeconomic imbalances.

After recovering from the financial crisis, Slovenia rebounced with the fifth wave of reforms and continued with the modernisation of public ad-

internalised the professional functioning of the administrative system, which is a key precondition for ensuring competitiveness and an appropriate business and creative environment.

8 An important step in reforming the Slovenian public administration was the establishment of an autonomous Ministry of Public Administration, which since its emergence in 2004 has acted not only as a government coordinator for reforms, but also for the entire public sector. More information about the Ministry of Public Administration is available at: https://www.gov.si/drzavni-organi/ministrstva/ministrstvo-za-javno-upravo/.

${ }^{9}$ More about the European administrative space in Brezovšek and Kukovič (2015, pp. 137-178). 
ministration. Throughout this period, umbrella strategic documents were adopted. In terms of digitalisation, Digital Slovenia 2020 - Development Strategy for the Information Society until 2020 was adopted in 2016, with the goal to bring intensive and innovative use of ICT and internet to all segments of the society. Furthermore, the Slovenian Government defined the key directions and modernisation of public administration development after the period of facing the economic crisis in the Public Administration Development Strategy 2015-2020 (2015). As this is the key document for our paper, we analyse it in the next chapter.

In Figure 1, we provide an overview of the Slovenian public administration reforms and adopted strategic documents. We have formatted five waves, caused by internal structural changes as well as triggers from the external (international) environment that coincide with the milestones of Slovenian state-building evolution.

Figure 1. Presentation of waves and strategic documents of the Slovenian public administration reforms

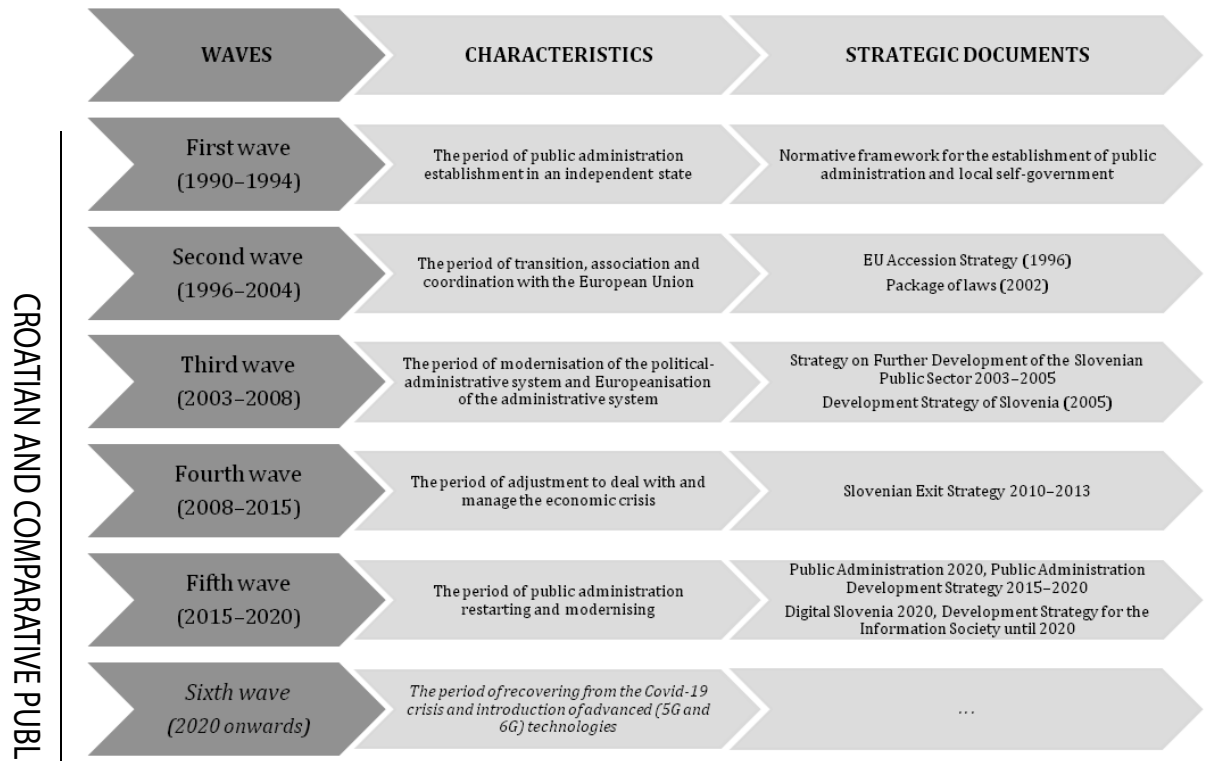

Source: Authors' own presentation.

Moreover, as a consequence of the current global health crisis, we predict a sixth, so called post-Covid-19 wave. Due to many repetitive lockdowns of different society segments and due to rapidly changing situations, it is urgent for the public administration to be dynamic and quickly adaptable 
to the new needs. It seems that modernisation, digitalisation and speed are the most sought-after characteristics of (public) administration. These characteristics will have to be further elaborated, exposed and highlighted in the upcoming reforms and in the future strategic document(s).

From what has been written, we can conclude that - as in other countries in the region ${ }^{10}$ - the reforms of the Slovenian public administration were shaped mostly through umbrella government strategies based on neo-liberal foundations of New Public Management, which in some places also contained elements of good governance (see Kovač \& Virant, 2011; Kovač \& Pevcin, 2017, pp. 307-308).

\section{Public Administration 2020, Public Administration Development Strategy 2015-2020}

On 29 April 2015, the Government of the Republic of Slovenia adopted a uniform umbrella strategic document entitled Public Administration 2020, Public Administration Development Strategy 2015-2020, which presents the guidelines for the development of public administration in the mentioned period. In addition to the modernisation and improvement of public administration in Slovenia, this document also contains the basis for a better environment for citizens and the economy, which affects the increase of social welfare and competitiveness of the whole country (Action Plan for Public Administration Development Strategy 2015-2020 for 2018 and 2019, 2018, pp. 1-2).

As announced in the introduction to this paper, we wanted to test whether, in accordance with modern theoretical doctrines, the current strategy is moving away from New Public Management and approaching modern, Post-New Public Management approaches. To this end, we performed an analysis of the set ten strategic goals and classified them into management approaches by finding an approach that includes the specific basic strategic goal. In Figure 2 , we present the conclusions of the analysis, ${ }^{11}$ emphasising alignment of each basic strategic goal only with the most obvious approaches.

\footnotetext{
10 See Koprić (2011); Kovač \& Bileisis (2017); Halili (2020, pp. 70-72).

11 We used the content analysis of the strategic goals explanation of the mentioned strategy. In the first step we created a list of parameters, i.e. the crucial characteristics of
} 
Figure 2. Placement of the basic strategic goals in individual approaches

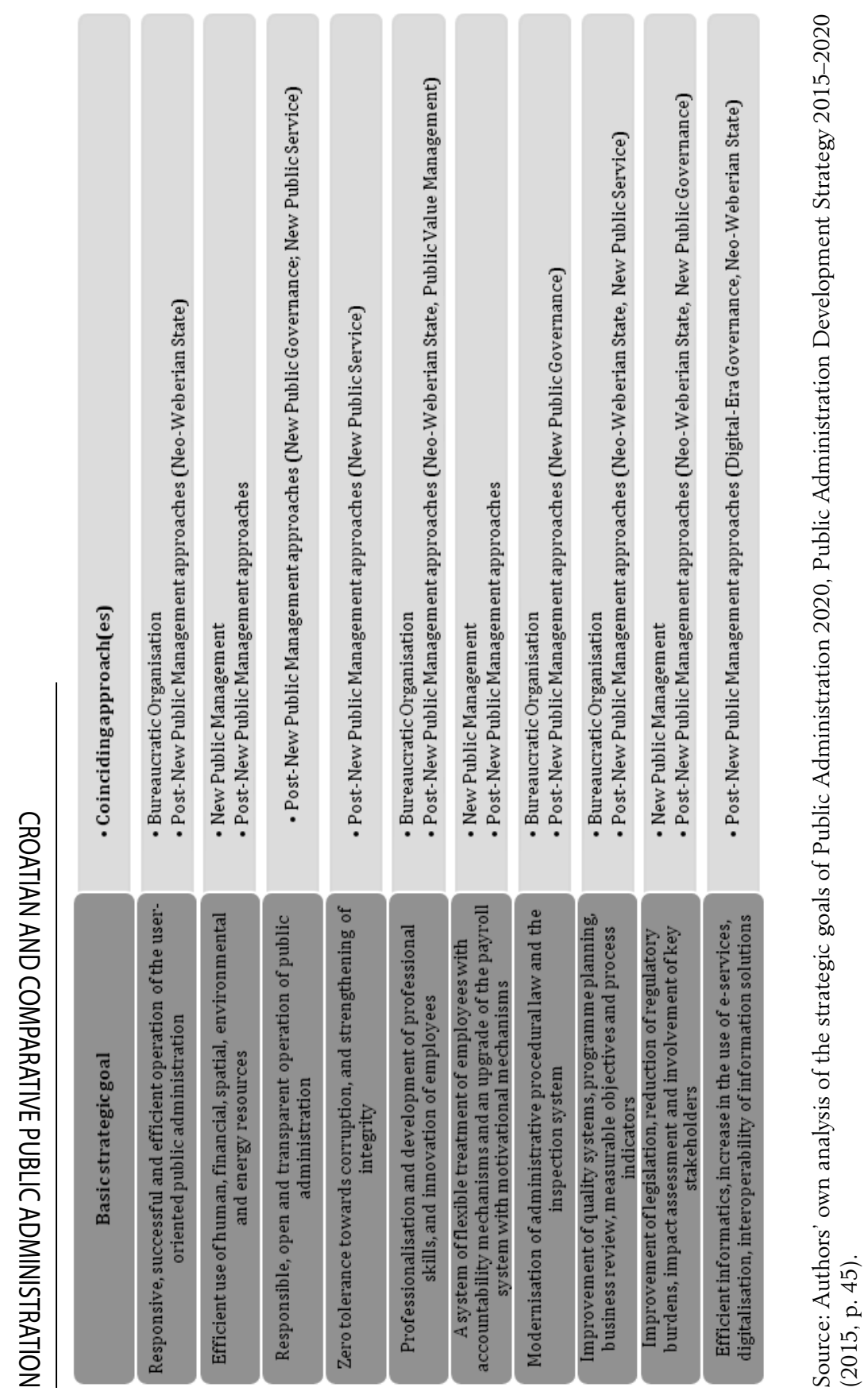


We find out that the basic strategic goals of the strategy coincide with different approaches and consequently form a conglomeration of different theoretical doctrines. The current strategy thus represents a hybrid of theoretical approaches to public governance. Despite the fact that Weber's bureaucratic organisation is already a somewhat outdated concept, its foundations are still used and serve as a basis for the development of modern approaches and the upgrade of strategic goals. Also, among the basic strategic goals are the principles of efficiency and effectiveness, which originate from the classical bureaucratic approach and were later further illuminated by New Public Management, but at the same time remain important elements of Post-New Public Management approaches, which have only slightly changed the way these principles are achieved and interpreted. Furthermore, the strategy contains many elements of Post-New Public Management approaches in its core strategic objectives, as it emphasises the citizens' involvement in processes, networking, and the participation of various stakeholders in law-making, horizontal integration, professionalism, digitalisation and introduction of e-services.

Furthermore, we are interested in the elements of which paradigms or approaches appear in this strategy. We tested the latter through the values that guided the designers in formulating strategic goals. We can observe that the values are related to the quality, efficiency, transparency and accountability of public administration and civil servants, higher level of professionalism, innovation, strengthening of internal control mechanisms to limit corruption risks, and systematic promotion of transparency and strengthening of fundamental values such as legality and rule of law, fairness, cooperation, and consensus orientation. The strategy also states that decisions and activities will be based on the expected benefits for users and their needs; the emphasis is also on responsiveness. ${ }^{12} \mathrm{We}$ can conclude that some set values are relatively general (i.e. responsibility, professionalism, legality, rule of law, etc.), which means that they are not specific to only one paradigm or approach to public administration, but appear in several approaches in which, however, they are interpreted and implemented in different ways.

Nevertheless, the analysis also reveals some values that we associate specifically with Post-New Public Management approaches. The obvious difference between New Public Management and Post-New Public Management approaches can be demonstrated in the case of consensus

12 See Public Administration 2020, Public Administration Development Strategy 2015-2020 (2015, p. 12). 
seeking, user orientation and involvement. At its core, New Public Management is not oriented towards consensus among various stakeholders, but rather towards the realisation of the interests of individuals. On the other hand, Post-New Public Management approaches intensively advocate the participation and involvement of citizens (as well as NGOs and other private sector stakeholders) in the search for a common interest. In addition, New Public Management is characterised by an understanding of the user in a strictly market sense, i.e. as a consumer, while Post-New Public Management approaches are user-oriented, deliberately appointed by citizens. The shift to Post-New Public Management approaches can also be illustrated by elements (included in the strategy) of transparency and the prevention of corruption. It was the latter that Post-New Public Management approaches eliminated as a result of many criticisms that accused New Public Management of insensitivity to corrupt practices.

In the analysis of the current strategy for the development of public administration, we point out another fact, namely that in the analysis of the ten basic strategic goals, we detected only eight chapters on operationalisation in terms of examining the existing situation and measures to achieve the goal. Pečarič (2015) argues that responsive, successful, and efficient operation of user-oriented public administration, and modernisation of administrative procedural law are strategic goals that are not directly included in the operationalisation of these goals, and wonders what the strategy actually reflects if key strategic objectives are not already covered in individual operationalisations. Nevertheless, both in the strategy itself and in the two subsequently adopted action plans, we perceive the operationalisation of the mentioned basic strategic goals within other chapters.

The latter is particularly important and worth considering as we are in the process of preparing a new strategy that requires even more intensive modernisation efforts. An evaluation of the current state of public administration (as well as its subsystems) was carried out - to a great extent accidentally - when an epidemic was declared, and revealed weaknesses, especially shortcomings in the transition to remote or electronic operation. Namely, we claim that the sixth wave of public administration reforms is beginning in Slovenia, which will be marked by adjustments for dealing with and managing post-crisis situations. Undoubtedly, this reform will be marked by a penitential period, as well as digitalisation or the so-called $5 \mathrm{G}$ standard. We must not forget that in some countries there is even a debate about the so-called $6 \mathrm{G}$ period. There is also a lot of controversy surrounding the $5 \mathrm{G}$ technology, not only in terms of administrative issues, 
but also in terms of security, privacy, as well as increasing power of the multinationals that establish and provide it. The latter is also associated with a number of issues and dilemmas of a more geopolitical nature, i.e. which country will have a decisive influence on the provision of these technologies. In other words, the fact that information will be (or already is) an increasingly important and valuable asset cannot be ignored.

\section{Conclusion: Where Are We and How to Proceed?}

Modern countries have numerous, diversified and strong administrations that play a central role in formulating and implementing public policies. According to Ackerman (2000), a modern state thus requires an entrepreneurial and active public administration that knows how to align with the practice of a successful democracy.-

Slovenian public administration has undergone quite a few reforms since its inception, which have always touched on the most basic concepts, such as democratisation of the society and public administration, human resources management, public administration efficiency, public administration in the information society, and training of civil servants (Kovač, 2000, p. 289). As shown, most public administration reforms in Slovenia took place (at least at a declarative level) within the framework of umbrella strategies, but we see a problem in the fact that the previous strategy was not evaluated before the adoption of the new strategy, and therefore the effects are relatively unknown. ${ }^{13}$

In this paper we put an emphasis on the currently (still) valid Public Administration Development Strategy 2015-2020. Our aim was to find out whether this strategy introduces elements into Slovenian public administration that go beyond the concept of New Public Management. As it is stated in the document, its main purpose is to update and modernise the public administration, which - as the text envisages - would become better in terms of quality services and legislation due to the values, goals, and measures to achieve these goals, as well as more efficient, professional, fair

13 In this sense, Kovač and Pevcin (2017, pp. 307-308) also explain that the adopted strategies may have pursued an explicit political or macroeconomic goal and that reforms were often carried out solely on the basis of a specific area or priority of the current government. 
and consensual, and would generally contribute to increasing prosperity in the country. Through the analysis of basic strategic goals, we sought to answer the question of which approaches or theoretical doctrines the strategy contains. We discovered that the foundations of Weber's bureaucratic organisation are still present, as the principles of efficiency and effectiveness serve as a basis for further development. However, the strategy also contains many elements of Post-New Public Management approaches, given that it emphasises citizen involvement in processes, networking, and the participation of various stakeholders in law-making, horizontal integration, professionalism, digitalisation and introduction of e-services. Furthermore, the highlighted values of the strategy are related to the quality, efficiency, transparency and accountability of public administration and civil servants, higher level of professionalism, innovation, strengthening of internal control mechanisms to limit corruption risks, and systematic promotion of transparency and strengthening of fundamental values such as legality and rule of law, fairness, cooperation, and consensus orientation. However, these values are not specific to only one paradigm, but are rather interpreted and implemented in several public administration approaches. On that basis we can conclude that the strategy represents a hybrid of theoretical approaches to public administration, but through the basic strategic goals, elements of Post-New Public Management approaches undoubtedly crystallise, which confirms our hypothesis.

Last but not least, the current situation (Covid-19 pandemic) shows us how urgent modernisation, digitalisation, high-quality, reliable and well-functioning public administration and a responsible, responsive, competent, and trustworthy public service are. Modern paradigms or approaches, which we have partially presented in this paper, provide us with a framework for establishing the necessary changes; on the decision makers, however, lies the intensity and scope of application of elements of Post-New Public Management approaches that would (gradually) transform the public administration hegemon into a dynamic, learning, and adaptable system through reforms.

\section{References}

Ackerman, B. (2000). The new separation of powers. Harvard Law Journal, 113(3), 628-695.

Action plan for public administration development strategy 2015-2020 for 2018 and 2019 (2018). Ljubljana: Government of the Republic of Slovenia Re- 
trieved from https://www.gov.si/assets/ministrstva/MJU/Kakovost-in-inovativnost-v-javni-upravi/Strategija/Dvoletni_akcijski_nacrt_SJU_2018-2019.pdf.

Brezovšek, M. (2000). Kako do zanesljive uprave? [How to get a reliable administration?]. Teorija in praksa, 37(2), 264-278.

Brezovšek, M., \& Kukovič, S. (2015). Evropska javna uprava [European public administration]. Ljubljana, Slovenia: Faculty of Social Sciences.

Brezovšek, M., Haček, M., \& Kukovič, S. (2014). Javna uprava [Public Administration]. Ljubljana, Slovenia: Faculty of Social Sciences.

Bučar, F. (1969). Uvod v javno upravo [Introduction to public administration]. Ljubljana, Slovenia: Časopisni zavod Uradni list Republike Slovenije.

Denhardt, B. R., \& Denhardt, J. V. (2000). The pew public service: Serving, not steering among. Public Administration Review, 60(6), 549-559, https://doi. org/10.1111/0033-3352.00117

Denhardt, R. B., \& Denhardt, J. V. (2003). The new public service: Serving, not steering among. New York, USA: M. E. Sharpe, https://doi.org/10.4324/9781 315699356

Development strategy of Slovenia. (2005). Ljubljana: Government of the Republic of Slovenia. Retrieved from https://www.umar.gov.si/fileadmin/user_upload/ projekti/02_StrategijarazvojaSlovenije.pdf.

Digital Slovenia 2020, Information society development strategy until year 2020. (2016). Ljubljana: Government of the Republic of Slovenia Retrieved from https://www.gov.si/assets/ministrstva/MJU/DID/Strategija-razvoja-informacijske-druzbe-2020.pdf.

Drechsler, W., \& Kattel, R. (2008). Towards the Neo-Weberian State? Perhaps, but Certainly Adieu, NPM! The NISPAcee Journal of Public Administration and Policy, 1(2), 95-99.

Dunleavy, P., Margetts, H., Bastow, S., \& Tinkler, J. (2005). New public management is dead - Long live digital-era governance. Journal of Public Administration Research and Theory, 16(3), 467-494, https://doi.org/10.1093/acprof:oso/9780199296194.003.0009

Dunn, W. N., \& Miller, D. Y. (2007). A critique of the new public management and the Neo-Weberian State. Public Organization review, 7(4), 345-358.

Fisher, T. (2014). Public value and the integrative mind. Public Administration Review, 74(4), 457-464.

Haček, M. (2006). The relationship between civil servants and politicians in a post-communist country: a case of Slovenia. Public Administration, 84(1), 165-184, https://doi.org/10.1111/j.0033-3298.2006.00498.x

Haček, M. (2012). The commitment of senior civil servants to democratic freedoms and equality. Transylvanian review of administrative sciences, 35(E), 93106.

Halili, R. (2020). Administrative burdens from the service users' perspective. Journal of Comparative Politics, 13(2), 65-85. 
Hughes, Q. E. (2003). Public management and administration. New York, USA: Palgrave, MacMillan.

Justinek, G. (2020). The (non) reforms of Slovenia's economy. The impact of European institutions on the rule of law and democracy. Oxford, UK: Hart Publishing, https://doi.org/10.5040/9781509915071.ch-004

Koprić, I. (2011). Contemporary Croatian public administration on the reform waves. Godišnjak Akademije pravnib znanosti Hrvatske, 2(1), 1-40, https://doi. org/10.32984/gapzh

Kovač, P. (2000). Javna uprava v znamenju ljudi [Public Administration in the Light of People]. Teorija in praksa, 37(2), 279-293.

Kovač, P. (2004). Novi javni menedžment in slovenska uprava [New public management and Slovenian administration]. In M. Brezovšek \& M. Haček (Eds.), Upravna kultura [Administrative culture] (pp. 177-196). Ljubljana, Slovenia: Faculty of Social Sciences.

Kovač, P., \& Bileišis, M. (Eds.) (2017). Public administration reforms in Eastern European Union member states, Post-accession convergence and divergence. Ljubljana \& Vilnius: Faculty of Administration \& Mykolas Romeris University.

Kovač, P., \& Pevcin, P. (2017). Slovene public administration reform: Europeanization as a bridge over traditional and post-socialist legacies. In P. Kovač \& M. Bileišis (Eds.), Public administration reforms in Eastern European Union member states, Post-accession convergence and divergence (pp. 302-338). Ljubljana \& Vilnius: Faculty of Administration \& Mykolas Romeris University, https://doi.org/10.24193/tras.2017.0008

Kovač, P., \& Virant, G. (2011). Razvoj slovenske javne uprave 1991- 2011 [Development of Slovenian public administration 1991 - 2011]. Ljubljana, Slovenia: Uradni list Republike Slovenije.

Letnar Černič, J., \& Justinek, G. (2020). Business and human rights in state owned enterprises - the case of Slovenia. International Journal of Public Sector Performance Management [in press].

Lodge, M., \& Gill, D. (2011). Towards a new era of administrative reform? Governance, 24(1), 141-166.

Ministry of Public Administration. (2020). Retrieved from https://www.gov.si/drzavni-organi/ministrstva/ministrstvo-za-javno-upravo/.

Olsen, J. P. (2003). Toward a European administrative space? Journal of European Public Policy, 10(4), 506-531.

Ongaro, E. (2013). The administrative reform trajectory of the EC in comparative perspective. Public Policy and Administration, 28(3), 346-363, https://doi. org/10.1177/0952076713481486

Osborne, S. (2006). The new public governance. Public Management Review, 8(3), 377-387, https://doi.org/10.4324/9780203861684

Osborne, S. (2010). The new public governance? Emerging perspective on the theory and practice of public governance. New York, USA: Routledge.

Pečarič, M. (2015). Predlog strategije razvoja javne uprave - analiza nezavednega in sistemskega pogleda [A draft strategy of development of public administra- 
tion - the analysis of unconscious and systematic view]. In A. Aristovik (Ed.), Slovenski javni sektor na razpotju strateškib sprememb: zbornik prispevkov [Slovenian Public Sector at the Crossroads of Strategic Change: Proceesings]. Ljubljana, Slovenia: Faculty of Administration.

Philippi, C., Bobek, V., Horvat, T., Maček, A., \& Justinek, G. (2020). Internationalisation of an Austrian SME with a sales agent to Mexico and the USA in the automotive sector. International journal of globalisation and small business, 11(1), 39-64, https://doi.org/10.1504/ijgsb.2020.10027230

Pollitt, C., \& Bouckaert, G. (2004). Public management reform: A comparative analysis. Oxford, UK: Oxford University Press.

Pollitt, C. \& Bouckaert, G. (2011). Public management reform: A comparative analysis. Oxford, UK: Oxford University Press.

Presentation of the strategic plan for the implementation of the public administration reform project in Slovenia in the period 1997-1999. (1997). Javna uprava, 33(2), 151-210.

Public administration 2020, Public administration development strategy 2015-2020. (2015). Ljubljana, Slovenia: Ministry of Public Administration. Retrieved from https:/www.gov.si/assets/ministrstva/MJU/Kakovost-in-inovativnost-v-javni -upravi/Strategija/Strategija_razvoja_SLO_final_web.pdf

Saint-Simon, C. H. (1979). Katekizem industrijalca. Izbor iz djela [Catechism of the industrialist. Selection from the work]. Zagreb, Croatia: Školska knjiga.

SIGMA/OECD. (1998). Preparing public administration for the European administrative space. SIGMA paper 23. Retrieved from http://unpan1.un.org/intradoc/ groups/public/documents/NISPAcee/UNPAN0 06800.pdf.

SIGMA/OECD. (1999). European principles for public administration. SIGMA paper 27. Retrieved from http://dx.doi.org/10.1787/5kml60zwdr7h-en.

Slovenian exit strategy 2010-2013. (2010). Ljubljana, Slovenia: Government office for development and European affairs. Retrieved from https://www. yumpu.com/xx/document/read/6161761/slovenska-izhodna-strategija-20102013-sluzba-vlade-republike-.

Stoker, G. (2006). Public value management: A new narrative for networked governance? American Review of Public Administration, 36(1), 41-57, https://doi. org $/ 10.1177 / 0275074005282583$

Strategy for further development of the Slovenian public sector 2003-2005. (2003). Ljubljana, Slovenia: Ministry of Interior.

Šmidovnik, J. (1985). Teoretične osnove upravljanja [Theoretical foundations of public governance]. Ljubljana, Slovenia: Univerzum.

Wilson, W. (1995). The study of public administration. Washington, USA: Public Affairs Press.

White paper on European governance. (2001). Brussels, Belgium: European Commission. Retrieved from http://europa.eu/rapid/press-release_DOC-01-10_en.htm. 


\section{MODERNISATION TRENDS IN PUBLIC ADMINISTRATION IN SLOVENIA}

\section{Summary}

The theory of public administration offers a wide range of paradigms or approaches that are developed as a consequence of various triggers from internal and external environment. The classical model of bureaucratic organization as outlined by Weber is no longer appropriate in modern countries, although it still remains the basis of public administration because of numerous transformations and upgrades. The first major reforms were introduced to public administration via the more modern and market-oriented New Public Management. However, Post-New Public Management approaches have recently developed as a reflection of social and political changes. In this paper, we offer an overview of modern approaches, which do not appear in pure form, but in the form of bybrids. There is no consensus, either in science or in practice, on the optimal direction of public administration development or on the preferential approach. This decision is left to the governments, bearing in mind that each public administration reform and hybridization of approaches affect the complexity of public administration. Analysing the reform of the Slovenian public administration, we have found that the current Strategy of Public Administration Development for 2015-2020 is based on modern elements and values of Post-New Public Management approaches and that reforms strive for modernization, but (as shown by the current crisis) a serious effort will be required in the future to achieve this goal.

Keywords: public administration, administrative reforms, administrative doctrines, modernisation, Slovenia 


\title{
MODERNIZACIJSKI TRENDOVI U SLOVENSKOJ JAVNOJ UPRAVI
}

\begin{abstract}
Sažetak
Teorija javne uprave razvila je niz paradigmi ili pristupa kao odgovor na različite pobude iz unutrašnje i vanjske okoline. U suvremenim zemljama klasični Weberov model birokratske organizacije nije više primjeren premda i dalje ostaje osnova javne uprave zabvaljujući mnogim promjenama $i$ poboljšanjima. Prve velike reforme u javnu su upravu uvedene zabvaljujući modernijem $i$ na tržište orijentiranom novom javnom menadžmentu, ali se $u$ novije vrijeme razvijaju $i$ suvremeniji (post-NJM) pristupi kao odraz društvenih $i$ političkih promjena. $U$ ovom se radu daje pregled modernib pristupa koji se ne pojavljuju u čistim oblicima nego kao bibridi. Ni u znanosti ni u praksi nema suglasnosti o optimalnom pravcu razvoja javne uprave ili o preferiranom pristupu. Odluka o tome prepušta se vlastima, s mišlju da svaka reforma javne uprave i miješanje pristupa utječe na složenost javne uprave. Analiza slovenske javne uprave pokazala je da je važeća Strategija reforme javne uprave za razdoblje 2015-2020 utemeljena na modernim elementima $i$ vrijednostima pristupa razvijenib poslije novog javnog menadžmenta, koji teže modernizaciji ali traže značajne napore da bi bili provedeni, kao što pokazuje trenutačna kriza.
\end{abstract}

Ključne riječi: javna uprava, upravne reforme, upravne doktrine, modernizacija, Slovenija 